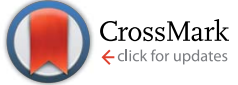

Cite this: J. Mater. Chem. A, 2015, 3, 22118

Received 15th July 2015

Accepted 14th September 2015

DOI: $10.1039 / c 5 t a 05380 c$

www.rsc.org/MaterialsA

\section{Synthesis and energetic properties of high-nitrogen substituted bishomocubanes $\uparrow$}

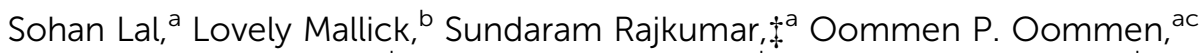 \\ Sasidharakurup Reshmi, ${ }^{\mathrm{d}}$ Neeraj Kumbhakarna, ${ }^{\text {tb }}$ Arindrajit Chowdhury ${ }^{* \mathrm{~b}}$ \\ and Irishi N. N. Namboothiri ${ }^{a}$
}

\begin{abstract}
Synthesis, thermodynamic characterization, and energetic properties of three novel high-nitrogen bishomocubane-based compounds DADMBHC, DTetzBHC and DPTrizDMBHC are reported here. These compounds have higher heats of formation (HoFs) and higher energy densities as compared to traditional hydrocarbon fuels. Densities, gas phase HoF and their optimized molecular structure geometries were calculated with various levels of theory. In general, the calculated HoFs of these compounds turn out to be extremely high. Ballistic properties such as vacuum specific impulse and density vacuum specific impulse were calculated using the NASA Chemical Equilibrium and Applications utility. Propulsive properties were compared with liquid bipropellants (RP1) and solid propellants (AP) and explosive properties were compared with RDX. The density specific impulse demonstrated an improvement of $35 \mathrm{~s}$ for DADMBHC and DTetzBHC over standard liquid hydrocarbon HTPB, thus showing promise as possible monomers to replace HTPB as a fuel-binder. The density specific impulses of these compounds were also found to be significantly higher than that of RP1, e.g. that of DADMBHC was found to be higher by $84 \mathrm{~s}$, making them potentially good candidates as propellants for use under volume-limited conditions. The detonation properties showed that these compounds have low potential as explosives. TGA, coupled with IR spectroscopy, revealed that DADMBHC and DPTrizDMBHC evaporate readily while DTetzBHC decomposes partially.
\end{abstract}

\section{Introduction}

High energy density materials (HEDMs) are common ingredients in various volume-limited applications demanding high performance parameters, such as rockets, gas generators, and explosives. Attractive properties of an ideal HEDM are high gravimetric and volumetric energy density, high positive HoF, high density, as well as low operational hazards such as low toxicity, high thermal stability, and low impact sensitivity. ${ }^{1}$ Cage hydrocarbons can potentially be good HEDMs on account of their severely strained molecular structures. Eaton et al. ${ }^{2}$ synthesized cubane, a polycyclic cage hydrocarbon and studied

${ }^{a}$ Department of Chemistry, Indian Institute of Technology Bombay, Mumbai 400076, India.E-mail: irishi@chem.iitb.ac.in; Fax: +9122 2576 7152, +9122 25723480 ${ }^{b}$ Department of Mechanical Engineering, Indian Institute of Technology Bombay, Mumbai 400076, India. E-mail: neeraj_k@iitb.ac.in; Fax: +9122 25726875

'Polymer Chemistry Group, Department of Materials Chemistry, The Angström Laboratory, Uppsala University, Box 538, SE-75121 Uppsala, Sweden

${ }^{d}$ Polymers and Special Chemicals Group, PCM Entity, Vikram Sarabhai Space Centre (VSSC), Thiruvananthapuram, Kerala 695022, India.E-mail: s_reshmi@vssc.gov.in $\dagger$ Electronic supplementary information (ESI) available: Computational data tables and NMR spectra. See DOI: 10.1039/c5ta05380c

\$ Present address: School of Chemistry, University of Leeds, Leeds LS2 9JT, UK, E-mail: R.Sundaram@leeds.ac.uk. its performance. Numerous studies have shown that cubane is energetically superior to conventional hydrocarbons. ${ }^{3,4}$ Since cubane is a solid under standard conditions, it can be used in solid propellant formulations as a possible energetic binder ${ }^{\mathbf{1}}$ by conversion to polymeric forms. It can also be used as an additive to fuels in liquid propulsion systems and in internal combustion engines. ${ }^{5}$ But for this to happen, formulation of stable binary mixtures of cubane with existing liquid propellants is necessary. This has prompted the propellant synthesis community to develop similar propellants by altering the basic cage structure of cubane and by adding energetic functional groups. $^{6-10}$ A thorough review of the synthesis of such compounds ${ }^{10-18}$ can be found in our previous work. ${ }^{19,20}$ Such efforts are primarily aimed at synthesizing liquid propellants with high energy densities, which can be utilized directly or as additives to existing liquid propellants. Marchand ${ }^{\mathbf{1 5}}$ has compiled a comprehensive review of the synthesis procedures of various homocubanes, bishomocubanes, and trishomocubanes. Polycyclic cage hydrocarbons have also been reviewed extensively. ${ }^{\mathbf{1 6 , 1 7 , 2 1}}$ Synthesis of these compounds is typically carried out only at milligram scales due the complexities involved in synthesis procedures. This constrains the experimental investigation of their combustion characteristics to measuring burn rates of propellant droplets individually, ${ }^{22}$ or as 
additives to existing liquid fuels, such as $n$-nonane, kerosene, and JP-10. The distinct energetic advantage in using the cage hydrocarbon is evident in a study by Roy, ${ }^{23}$ which focuses on analysing mixtures of methylcubane and a conventional hydrocarbon (n-nonane). The cage hydrocarbon burns twice as fast as a conventional hydrocarbon. Because of the limited synthesis yield, experimental studies on these HEDMs have to be restricted to pyrolysis, thermogravimetric analysis, etc. ${ }^{\mathbf{2 4 , 2 5}}$ In our previous study, ${ }^{19}$ the thermal decomposition of newly synthesized bis(nitratomethyl)-1,3-bishomocubane (DNMBHC) was analysed using a fast pyrolyzer coupled with rapid scan FTIR spectroscopy at a heating rate of $100{ }^{\circ} \mathrm{C} \mathrm{s}^{-1}$. The evolved gas analysis showed that the primary decomposition takes place resulting in the formation of $\mathrm{CO}_{2}, \mathrm{~N}_{2} \mathrm{O}, \mathrm{NO}_{2}, \mathrm{CO}$, and $\mathrm{H}_{2} \mathrm{O}$. The formulation of a detailed chemical reaction mechanism for DNMBHC using $a b$ initio methods is currently underway. Computational analysis at the DFT/ab initio level carried out on newly synthesized and characterized nitrosubstituted bishomocubanes, viz. nitromethyl-1,3-bishomocubane (NMBHC), nitromethylene-1,3-bishomocubane (NMyBHC) and bis-nitromethyl-1,3-bishomocubane (DNTMBHC), showed that they possess high positive HoFs and high density specific impulses and therefore are superior to hydrocarbon fuels such as RP1 with regard to their propulsive performance. They could prove to be useful in spite of being costlier than RP1. ${ }^{18}$ Previous analyses have revealed that RP1 consists of 24 major constituents ranging from 11 carbon fluids such as 2,6-dimethylnonane to 15 carbon fluids such as 2-methyltridecane. Other than cage hydrocarbons, high-nitrogen materials have also received considerable attention as potential HEDMs. They produce large amounts of molecular nitrogen on decomposition and have high positive heats of formation. ${ }^{26}$ Their adiabatic flame temperatures are often lower compared to conventional propellants, and they have the potential to form less smoke or soot. In addition, some of the high-nitrogen materials are remarkably stable towards friction, heat and impact, and hence are easy to store and transport. ${ }^{26}$ These properties of highnitrogen materials make them suitable for numerous applications such as in airbags and gun propellants. Tetrazoles ${ }^{27-31}$ and triazoles $^{32-35}$ are classes of high-nitrogen materials that have received a considerable attention in the literature with regard to their behavior as energetic materials. They have been extensively studied computationally as well as experimentally to investigate their energetic characteristics and chemical kinetics.

The current work entails a systematic investigation of the thermodynamic and thermal characteristics of three newly synthesized high nitrogen-BHC-based compounds, i.e., diazido-dimethyl-bishomocubane (DADMBHC), ditetrazolobishomocubane (DTetzBHC), and diphenyltriazolo-dimethylbishomocubane (DPTrizDMBHC). Ab initio methods were utilized to optimize the geometry and determine the thermodynamic characteristics while thermogravimetry combined with Fourier transform infrared (FTIR) spectroscopy was employed to elucidate the thermal behaviour of these compounds and to identify their thermal decomposition pathways. The detonation characteristics such as detonation pressure and detonation velocity as well as the propulsive performance parameters such as specific impulse and density specific impulse were calculated using semi-empirical methods and equilibrium thermodynamics, respectively. Chemical reactions initiating the decomposition were also postulated using ab initio methods.

\section{Computational approach}

To investigate the thermodynamic properties and decomposition pathways of the three high-nitrogen bishomocubanes DADMBHC (2), DPTrizDMBHC (3), and DTetzBHC (5) (Scheme 1 , vide infra) which are the subject of this work; quantum mechanics based calculations were carried out using the Gaussian 09 suite of programs. ${ }^{36}$ Optimization of the molecular structures of these compounds and their estimated decomposition products was first carried out by using the B3LYP/6$31 \mathrm{G}(\mathrm{d})$ level of theory. ${ }^{37,38}$ The optimized structures served as an initial guess for the B3LYP/6-311G(d,p) level of theory which employs a triple split valence basis set with additional polarized functions. ${ }^{39}$ Since molecules of the compounds under consideration are considerably large we also analyzed them by using the B3LYP exchange correlation functional after including diffuse functions ${ }^{\mathbf{4}}$ in the $6-31 \mathrm{G}$ basis set. All the levels of theory mentioned above were selected to maintain a balance between the computational time and accuracy. ${ }^{41-43}$ HoFs of all the compounds under study were calculated using the method given by Osmont et al. ${ }^{44}$ for B3LYP/6-31G(d,p) and that given by Nicolaides et $a .^{45}$ for other levels of theory. The densities of the compounds were calculated using the same molecular orbital theories by dividing the molecular weights of the compounds by the respective molar volumes, determined on the basis of the $0.001 \mathrm{e} \mathrm{bohr}^{-3}$ density envelope through the Monte-Carlo method. ${ }^{46}$ Using the results of quantum mechanics based calculations, thermodynamic properties such as specific heat, enthalpy, entropy, Gibbs free energy, etc. were calculated for each compound through frequency calculations and a database of thermodynamic properties was created. This database, given in Table S1 in the ESI, $\uparrow$ can be conveniently used in computational models simulating the combustion phenomenon involving the compounds.

Ballistic properties such as vacuum specific impulse ( $\left.I_{\text {sp,vac }}\right)$ and density vacuum specific impulse $\left(\rho I_{\mathrm{sp}, \mathrm{vac}}\right)$ were calculated using the NASA CEA (Chemical Equilibrium and Applications)

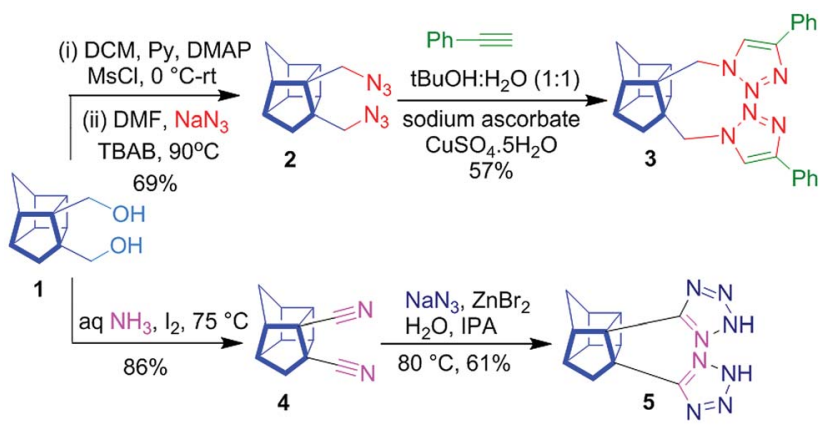

Scheme 1 
utility. ${ }^{47}$ For assessing the performance of these compounds as bipropellants with liquid oxygen as the oxidizer, as well as solid propellants with ammonium perchlorate (AP) as the oxidizer, the chamber pressure and exit-to-throat area ratio were taken to be 1000 and $70 \mathrm{psi}$, respectively. As per the commonly followed procedure, while calculating $I_{\mathrm{sp}, \mathrm{vac}}$ of the liquid propulsion systems, the mixture ratio (oxidizer to fuel ratio) for which the specific impulse is maximum was first calculated for the expansion of the combustion products from $1000 \mathrm{psi}$ to atmospheric pressure. This mixture ratio was then used to determine the recorded $I_{\text {sp,vac }}$ by simulating the combustion products through an area ratio of 70 . The heat of combustion of the compounds was calculated by assuming complete combustion by gaseous oxygen as shown in eqn (1)-(3). HoFs of $\mathrm{H}_{2} \mathrm{O}$ and $\mathrm{CO}_{2}$ were taken to be $-57.79 \mathrm{kcal} \mathrm{mol}^{-1}$ and $-94.05 \mathrm{kcal} \mathrm{mol}^{-1}$, respectively, from the NIST database. ${ }^{48}$

$$
\begin{gathered}
\mathrm{C}_{12} \mathrm{H}_{14} \mathrm{~N}_{6}+15.5 \mathrm{O}_{2} \rightarrow 12 \mathrm{CO}_{2}+7 \mathrm{H}_{2} \mathrm{O}+3 \mathrm{~N}_{2} \\
\mathrm{C}_{12} \mathrm{H}_{12} \mathrm{~N}_{8}+15 \mathrm{O}_{2} \rightarrow 12 \mathrm{CO}_{2}+6 \mathrm{H}_{2} \mathrm{O}+4 \mathrm{~N}_{2} \\
\mathrm{C}_{28} \mathrm{H}_{26} \mathrm{~N}_{6}+34.5 \mathrm{O}_{2} \rightarrow 28 \mathrm{CO}_{2}+13 \mathrm{H}_{2} \mathrm{O}+3 \mathrm{~N}_{2}
\end{gathered}
$$

Oxygen balance, ${ }^{49}$ defined as the percentage of intrinsic oxygen available for combustion, of a compound having a molecular formula $\mathrm{C}_{a} \mathrm{H}_{b} \mathrm{~N}_{c} \mathrm{O}_{d}$ and molecular weight MW, was calculated using eqn (4).

$$
\mathrm{OB}(\%)=\frac{-32\left(a+\frac{1}{4} d-\frac{1}{2} d\right)}{\mathrm{MW}} \times 100
$$

The detonation properties of the high-nitrogen bishomocubanes were calculated using the Kamlet-Jacobs empirical correlations. $^{50}$ As these compounds do not contain oxygen, it was assumed that upon detonation, they form $\mathrm{N}_{2}, \mathrm{H}_{2}$, and solid carbon. The detonation pressure $P$ (kbar) and detonation velocity $D\left(\mathrm{~km} \mathrm{~s}^{-1}\right)$ were calculated using computationally estimated HoFs and densities, using the following empirical correlations (eqns (5) and (6)):

$$
\begin{gathered}
P=15.58 \rho^{2} N M_{\mathrm{av}}{ }^{1 / 2} Q^{1 / 2} \\
D=1.01 \sqrt{N M_{\mathrm{av}}{ }^{1 / 2} Q^{1 / 2}}(1+1.3 \rho)
\end{gathered}
$$

where, $\rho\left(\mathrm{g} \mathrm{cm}^{-3}\right)$ is the density of the compound, $M_{\mathrm{av}}\left(\mathrm{g} \mathrm{mol}^{-1}\right)$ is the average molecular weight of the gaseous products, $N$ $\left(\mathrm{mol} \mathrm{g}^{-1}\right)$ is the number of moles of gaseous products per gram of explosive and $Q\left(\mathrm{cal} \mathrm{g}^{-1}\right)$ is the enthalpy of detonation.

Elementary analysis of the thermal decomposition pathways of these compounds was also carried out using quantum mechanics based calculations. Optimized structures of various intermediates and reaction products were obtained and the bond dissociation energies (BDEs) were estimated. Details of the computational time required for optimization and frequency calculations on some selected large molecules in this work are given in Table S2 in the ESI. $\dagger$

\section{Results and discussion}

Bishomocubanedicarbinol $\mathbf{1}^{\mathbf{5 1 , 5 2}}$ which was prepared in five steps from readily available dicyclopentadiene was an excellent substrate for the synthesis of bishomocubanes with high nitrogen substituents (Scheme 1). Treatment of bishomocubanedicarbinol 1 with mesyl chloride in the presence of pyridine and DMAP at $0{ }^{\circ} \mathrm{C}$ for $2 \mathrm{~h}$ followed by reaction with $\mathrm{NaN}_{3}$ in $\mathrm{DMF}$ provided 2 as a colorless liquid in $69 \%$ yield. The click reaction of 2 with phenylacetylene in the presence of $\mathrm{CuSO}_{4} \cdot 5 \mathrm{H}_{2} \mathrm{O}$ and sodium ascorbate afforded 3 as a white powdery solid in $57 \%$ yield. In another scheme, bishomocubanedicarbinol 1 was treated with iodine and aq. $\mathrm{NH}_{3}$ to provide DCBHC 4 in $86 \%$ yield. DCBHC 4 was then treated with sodium azide in the presence of $\mathrm{ZnBr}_{2}$ to afford DTetzDMBHC 5 in $61 \%$ yield. The structures of compounds 2-5 were assigned by detailed analysis of their spectroscopic data.

\section{Structural and thermodynamic properties}

Optimized geometries of the molecular structures of three highnitrogen containing bishomocubanes 2, 3 and 5 are shown in Fig. 1 and the atomic coordinates are provided in Tables S3-S5 (see ESI $\dagger$ ). The structure of ditetrazolo-dimethyl-bishomocubane (DTetzDMBHC 6) is also shown for the sake of comparison. All these structures were obtained using the B3LYP/6$31++\mathrm{G}(\mathrm{d}, \mathrm{p})$ level of theory. Table S6 (ESI $\dagger$ ) shows the selected bond lengths for the compounds 2, 3 and 5. The ideal unstrained $\mathrm{C}-\mathrm{C}$ bond length in the bishomocubane-based cage skeleton is $1.54 \AA$. Following the numbering convention for atoms given in Table S6, $\uparrow$ the variation of cage bond lengths for 2 is from 1.5302 (C7-C15) to 1.5969 (C1-C2) $\AA$, for 5 it is from 1.5308 (C7-C15) to 1.6183 (C1-C2) $\AA$ and for 3 it is from 1.5298

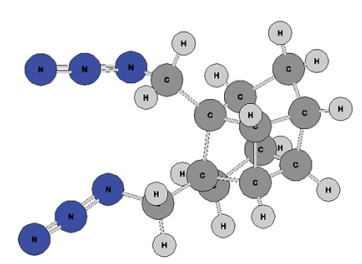

DADMBHC

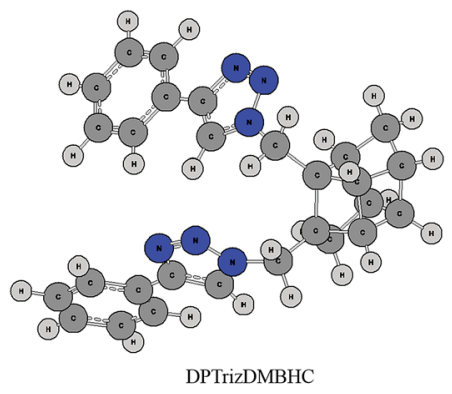

(4)- Hydrogen
DPTrizDMBHC

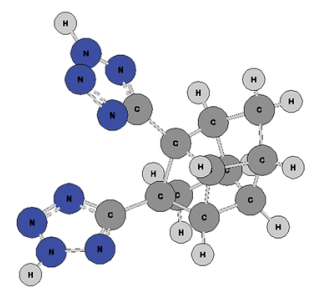

DTetzBHC

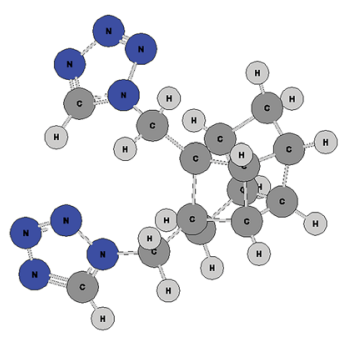

DTetzDMBHC
Fig. 1 Optimized structures of high-nitrogen containing bishomocubanes obtained using the B3LYP/6-31++G $(d, p)$ level of theory. 
(C7-C15) to 1.6077 (C1-C2) A. This shows that the presence of substituents causes considerable strain in the cage skeleton. These numbers also show that the magnitude of strain is independent of the nature of the substituent. The C1-C21 and C2-C22 bond lengths in both 2 and 3 are within the range of typical values observed in bonds involving $\mathrm{sp}^{3}$ hybridized $\mathrm{C}$ atoms. ${ }^{53}$ Similar observations can be made for $\mathrm{C}_{\text {Methyl }}-\mathrm{N}_{\mathrm{Azo}}$ bonds in $2, \mathrm{C}_{\text {cage }}-\mathrm{C}_{\text {Tetz }}$ bonds in $\mathbf{5}$ and $\mathrm{C}_{\text {Methyl }}-\mathrm{N}_{\text {Triz }}$ bonds in $\mathbf{3}$. Values of bond angles are given in Table S7. $\dagger$ All $\mathrm{C}-\mathrm{C}-\mathrm{C}$ angles in the cage deviate from the basic unstrained tetrahedral angle of $109.5^{\circ}$. For all the three compounds, angles in the cyclobutane structure within the cage deviate the most i.e. $\angle \mathrm{C} 2-\mathrm{C} 1-\mathrm{C} 5, \angle \mathrm{C} 1-\mathrm{C} 2-\mathrm{C} 11, \angle \mathrm{C} 1-\mathrm{C} 5-\mathrm{C} 11, \angle \mathrm{C} 5-\mathrm{C} 7-\mathrm{C} 12$ and $\angle \mathrm{C} 5-\mathrm{C} 11-\mathrm{C} 12$. Similar traits were observed by Lal $e t$ al. in the structures of nitro-substituted bishomocubanes. ${ }^{20}$

Gas phase HoFs of the high-nitrogen bishomocubanes are shown in Table 1. Although there is a substantial variation in the values of HoFs with various levels of molecular orbital theory, the overall trend in all the compounds for a particular level of theory is consistent. In addition to B3LYP, calculations were also performed on all the compounds using the M062X method. M062X is a high-nonlocality functional developed by Zhao and Truhlar $^{54}$ for thermochemistry, thermochemical kinetics, noncovalent interactions, and excited states. For HoF, it is advisable to rely on the values calculated using B3LYP/6-31++G(d,p) because for this basis set diffuse functions are included in all the hydrogen atoms in addition to heavy atoms. Such a basis set is recommended for large molecules. ${ }^{55}$ The HoF increases in the order of $2<5<3$. Also, the HoF increases slightly when additional methylene $\left(\mathrm{CH}_{2}\right)$ groups are substituted in $\mathbf{5}$ forming DTetzDMBHC 6. In general, the calculated HoFs of these compounds turn out to be high which is typical of high-nitrogen compounds. ${ }^{56}$ The HoF of 1,3-bishomocubane was found by Dilling ${ }^{57}$ to be $47.8 \mathrm{kcal} \mathrm{mol}^{-1}$ and high-nitrogen substituents are very likely to increase it from this value.

The densities of high-nitrogen bishomocubanes calculated as described in the previous section using various levels of theory are listed in Table 2. Unlike HoF, density values for different compounds do not follow the same trend for all levels of theory. As stated earlier, the most trustworthy values would be those calculated using B3LYP/6-31++G(d,p). The M062X theory which shows the same trend is also reliable and has a significant presence in recent literature. ${ }^{58,59}$

Table 1 Gas phase heats of formation of high-nitrogen bishomocubanes using various levels of theory ${ }^{a}$

Heat of formation $\left(\mathrm{kcal} \mathrm{mol}^{-1}\right)$

\begin{tabular}{llllll} 
Compound & A & B & C & D & E \\
\hline DADMBHC & 195.6 & 250.8 & 253.7 & 265.7 & 224.5 \\
DTetzBHC & 209.4 & 262.5 & 261.1 & 271.4 & 226.6 \\
DPTrizDMBHC & 231.7 & 322.2 & 325.5 & 347.8 & 262.5 \\
DTetzDMBHC & 213.5 & 275.6 & 272.8 & 286.4 & 230.0
\end{tabular}

${ }^{a}$ A: B3LYP/6-31G(d,p); B: B3LYP/6-311G(d,p); C: B3LYP/6-31+G(d,p); D: B3LYP/6-31++G(d,p); E: M062X/6-31+G(d,p).
Table 2 Densities of high-nitrogen bishomocubanes using various levels of theory ${ }^{a}$

\begin{tabular}{lllll}
\hline Density $\left(\mathrm{g} \mathrm{cm}^{-3}\right)$ & \multicolumn{1}{l}{} \\
\hline Compound & $\mathrm{A}$ & $\mathrm{B}$ & $\mathrm{C}$ & $\mathrm{D}$ \\
\hline DADMBHC & 1.32 & 1.37 & 1.38 & 1.57 \\
DTetzBHC & 1.51 & 1.53 & 1.54 & 1.76 \\
DPTrizDMBHC & 1.22 & 1.53 & 1.19 & 1.32 \\
DTetzDMBHC & 1.23 & 1.50 & 1.32 & 1.54 \\
a A: B3LYP/6-311G(d,p); B: B3LYP/6-31+G(d,p); C: B3LYP/6-31++G(d,p); \\
D: M062X/6-31+G(d,p).
\end{tabular}

One of the main objectives of the computational analysis of energetic materials is to predict data that are otherwise unavailable experimentally. Thermodynamic properties discussed in the previous section are examples of such data. The database generated by our calculations for calculating these thermodynamic properties is given in Table S1 (ESI $\dagger$ ) in the standard Chemkin ${ }^{60}$ format.

\section{Propulsive and ballistic properties}

It should be noted that the gas-phase HoFs of the compounds were used to calculate the ballistic and propulsive properties. Since the liquid or solid-phase HoFs are lower than the gasphase HoFs, the predicted ballistic and explosive performance would be higher than the actual performance. Comparison of various ballistic and propulsive properties of the high-nitrogen bishomocubanes is shown in Tables 3-6. For liquid propulsion systems with liquid oxygen as the oxidizer, the performance of the compounds was compared against the liquid hydrocarbon RP1. ${ }^{61,62}$ It should be noted that 5 and 3, being solids, were assumed to form a $30 \%$ solution (by mass) with Rocket Propellant 1 (RP1) while calculating their specific impulse as fuels in liquid propulsion systems. Calculations using NASA CEA show that the $I_{\mathrm{sp}}$ value does not change considerably if the mixture composition of RP1 with the respective compound is changed.

Data in Table 3 show that as far as the specific impulse is concerned, the mixture of RP1 and 5 and that of RP1 and 3 perform in a fashion similar to the commonly used liquid propellant RP1 when used with liquid oxygen as the oxidizer whereas 2 performs slightly better. However, the density specific impulses of these compounds were found to be significantly higher than that of RP1, making them potentially good candidates as propellants for use under volume-limited conditions. Nitro-substituted bishomocubanes studied earlier show similar characteristics. ${ }^{20}$ Although the HoFs of high-nitrogen bishomocubanes are significantly higher than that of RP1, this high energy content does not reflect in their $I_{\mathrm{sp}}$ values. The $I_{\mathrm{sp}}$ of a propellant composition depends on various factors in addition to its HoF such as the square root of the ratio of adiabatic flame temperature to the molecular weights of product gases. ${ }^{63}$ This parameter is shown in Table 3 for the compounds studied in this work. Therefore, although the 5 and $\mathbf{3}$ based compositions have higher HoFs and combustion chamber temperatures than 
Table 3 Comparison of predicted propulsive properties as liquid bipropellants

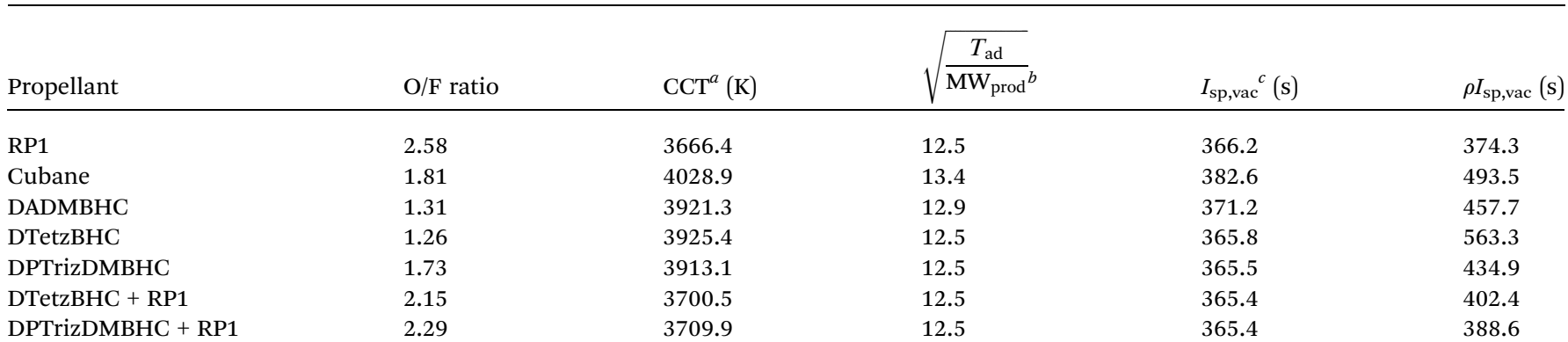

${ }^{a} \mathrm{CCT}$ - combustion chamber temperature. ${ }^{b}$ Root of the ratio of adiabatic flame temperature to the molecular weight of the products. ${ }^{c}$ With liquid oxygen as oxidizer at a chamber pressure of $1000 \mathrm{psi}$, and an area ratio of 70 .

RP1, their combustion products are heavier resulting in lower $I_{\mathrm{sp}}$. Propulsive properties of cubane, a similar solid cage hydrocarbon, are also listed. For the sake of comparison, cubane has been analyzed as a liquid and we see that its specific impulse is considerably higher than that of the other compounds. Composition of exhaust gases obtained during the combustion of the compounds under study shown in Table 4 sheds more light on their propulsive behavior. The cause of gain in $I_{\mathrm{sp}}$ for 2 over RP1 is most likely the formation of $\mathrm{N}_{2}$ which is typically responsible for high energy release in nitrogen containing compounds. A similar gain cannot be observed in $\mathbf{5}$ and 3 because they are in a mixture with RP1 and are not able to form as much $\mathrm{N}_{2}$ on combustion. Also concentrations of $\mathrm{CO}$ and $\mathrm{CO}_{2}$ are almost the same in the combustion products of the mixtures of these two compounds with RP1. Whereas in the case of 2 relatively more $\mathrm{CO}$ is formed as compared to $\mathrm{CO}_{2}$ giving the product gas a lower molecular weight.

The possibility of replacing hydroxyl-terminated polybutadiene (HTPB) as a non-energetic component in ammonium perchlorate (AP)-based solid propellant formulations was also investigated, and the results are tabulated in Table 5. 2 and 5 show an improvement of about 35 seconds in the specific impulse over НTPB, thus showing promise as possible ingredients to replace HTPB as a binder. But further investigation is needed to explore whether these compounds can be successfully polymerized before they can be considered for use as binders.

Table 6 lists the detonation properties of high-nitrogen bishomocubanes along with the commonly used explosive RDX. All of them have a negative oxygen balance implying that they are oxygen-deficient compounds and should be mixed with

Table 4 Mole fractions of major product species at the nozzle exit

\begin{tabular}{lcclll}
\hline $\begin{array}{l}\text { Product } \\
\text { species }\end{array}$ & Mol. wt & RP1 & DADMBHC & $\begin{array}{l}\text { RP1 } \\
\text { DPEHC }+\end{array}$ & $\begin{array}{l}\text { DPTrizBHC } \\
+ \text { RP1 }\end{array}$ \\
\hline $\mathrm{CO}$ & 28 & 0.23 & 0.36 & 0.26 & 0.27 \\
$\mathrm{CO}_{2}$ & 44 & 0.26 & 0.18 & 0.25 & 0.25 \\
$\mathrm{H}_{2}$ & 2 & 0.12 & 0.14 & 0.12 & 0.12 \\
$\mathrm{H}_{2} \mathrm{O}$ & 18 & 0.36 & 0.17 & 0.32 & 0.32 \\
$\mathrm{~N}_{2}$ & 28 & - & 0.13 & 0.03 & 0.01
\end{tabular}

Table 5 Comparison of predicted propulsive properties as solid propellants with ammonium perchlorate $(80 \%)^{a}$

\begin{tabular}{ll}
\hline Propellant & $I_{\mathrm{sp}, \mathrm{vac}}(\mathrm{s})$ \\
\hline HTPB & 274.6 \\
DADMBHC & 308.9 \\
DTetzBHC & 308.4 \\
DPTrizDMBHC & 294.7
\end{tabular}

${ }^{a}$ At a chamber pressure of $1000 \mathrm{psi}$, and an area ratio of 70 .

oxygen to assist combustion, and are not suitable candidates as monopropellants. The heats of combustion of 2, 5 and 3 , assuming complete combustion, were found to be $30.84 \mathrm{MJ} \mathrm{kg}^{-1}, 27.13 \mathrm{MJ} \mathrm{kg}^{-1}$ and $34.7 \mathrm{MJ} \mathrm{kg}^{-1}$, respectively. 2 and 5 are less oxygen deficient and have a higher percentage of nitrogen in their molecule than $\mathbf{3}$ and hence perform better as explosives as compared to $\mathbf{3}$. 5 has the highest detonation pressure and detonation velocity among the three compounds because it is the richest in nitrogen. In contrast, 3 has a carbonrich structure and does not appear to be explosive in nature.

The adiabatic flame temperatures $\left(T_{\mathrm{ad}}\right)$ of high-nitrogen bishomocubanes were calculated at a pressure of 69 bar with liquid oxygen as the oxidizer and at different equivalence ratios $(\varphi)$. Assuming complete oxidation of the reactant species, it was found that the highest calculated $T_{\text {ad }}$ for 2, 5 and 3 was $3946.2 \mathrm{~K}$ $(\varphi=1.35), 3928.3 \mathrm{~K}(\varphi=1.35)$ and $3921 \mathrm{~K}(\varphi=1.32)$, respectively. These are approximately $300 \mathrm{~K}$ higher than the $T_{\text {ad }}$ calculated for RP1. The high adiabatic flame temperatures were attributed to the high HoF of these compounds.

Table 6 Comparison of predicted explosive properties ${ }^{a}$

\begin{tabular}{lccc}
\hline Propellant & OB (\%) & D.P. ${ }^{b}(\mathrm{GPa})$ & D.V. $^{c}\left(\mathrm{~km} \mathrm{~s}^{-1}\right)$ \\
\hline RDX $(\mathrm{g})$ & -21.62 & 35.1 & 8.93 \\
DADMBHC (g) & -204.95 & 12.72 & 5.84 \\
DTetzBHC (g) & -179.10 & 15.45 & 6.20 \\
DPTrizDMBHC (g) & -247.53 & 5.80 & 4.17 \\
& \\
${ }^{a}$ Calculated using & Kamlet-Jacobs correlations. & ${ }^{b}$ D.P. - detonation \\
pressure. ${ }^{c}$ D.V. - detonation velocity.
\end{tabular}




\section{Thermal characterization}

The thermal characterization of these compounds is an important exercise since it determines their suitability as propellants or explosives, revealing vital information regarding their thermal decomposition mechanisms during combustion as well as storage. The standard hyphenated technique of thermogravimetric (TGA) analysis attached to a Fourier Transform Infra-Red (FTIR) spectrometer was utilized for this purpose. Under standard conditions, 2 is a viscous liquid, while $\mathbf{3}$ and $\mathbf{5}$ are both crystalline solids. The TGA and differential thermogravimetry (DTG) signals for $\mathbf{2 ,} 3$, and $\mathbf{5}$ are shown in Figs. 2-4. It should be noted that due care must be taken while interpreting TGA signals of cage hydrocarbons, due to the possibility of mass loss caused by evaporation or sublimation, instead of thermal decomposition. The TGA curve in Fig. 2 shows that a complete mass loss occurred in a single stage for 2, with an extrapolated onset temperature of $157{ }^{\circ} \mathrm{C}$, an extrapolated end temperature of $202{ }^{\circ} \mathrm{C}$, and a single DTG peak at $194{ }^{\circ} \mathrm{C}$. Similarly, the TGA signal from 3 in Fig. 3 shows a single stage mass loss of approximately $90 \%$, with an onset temperature of $357{ }^{\circ} \mathrm{C}$, which is $200{ }^{\circ} \mathrm{C}$ higher than the azide based compound, an end temperature of $397^{\circ} \mathrm{C}$, and a single DTG peak at $382^{\circ} \mathrm{C}$. Fig. 4 demonstrates that 5 is different from the other two compounds, with the mass loss occurring in two stages - the first stage being defined by an onset temperature of $245{ }^{\circ} \mathrm{C}$, an end temperature of $263{ }^{\circ} \mathrm{C}$, a DTG peak at $251{ }^{\circ} \mathrm{C}$, and a mass loss of approximately $26 \%$; the second stage being defined by an onset temperature of $407{ }^{\circ} \mathrm{C}$, and a DTG peak at $450{ }^{\circ} \mathrm{C}$, and also an approximate mass loss of $26 \%$. Our previous studies showed that the onset temperature of thermal decomposition of bis(nitrato-methyl)-bishomocubane was 140 ${ }^{\circ} \mathrm{C},{ }^{19}$ while the onset temperature of evaporation for nitro compounds NMBHC, NMyBHC, and DNTMBHC, was $148{ }^{\circ} \mathrm{C}$, $160{ }^{\circ} \mathrm{C}$, and $205{ }^{\circ} \mathrm{C}$, respectively. ${ }^{20}$ Additionally, several iodo derivatives of cubane also had onset temperatures ranging from 103 to $206{ }^{\circ} \mathrm{C}^{64}$ Comparatively, the onset temperature of the parent compound, 1,3-bishomocubane was $168{ }^{\circ} \mathrm{C}$, and those of its poly-nitro-derivatives were approximately $100{ }^{\circ} \mathrm{C}$ higher. ${ }^{65}$ In order to ascertain the processes governing the loss of mass during the TGA experiments, the FTIR spectra of the

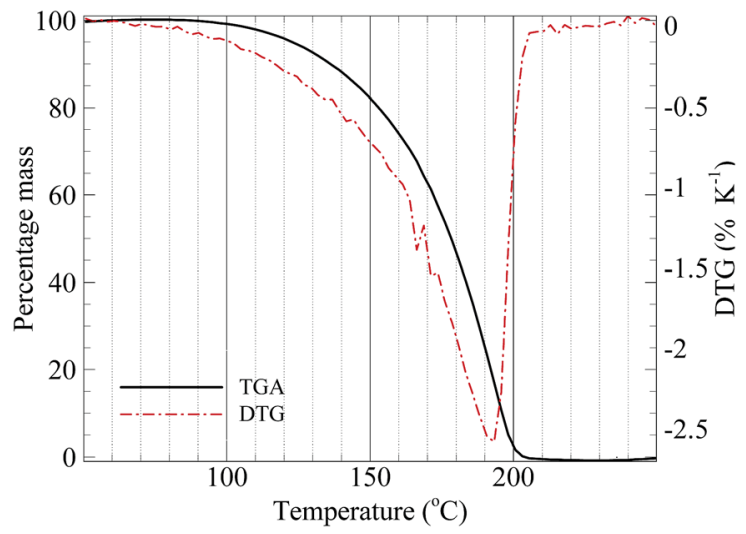

Fig. 2 TGA-DTG of DADMBHC at $10 \mathrm{~K} \mathrm{~min}^{-1}$.

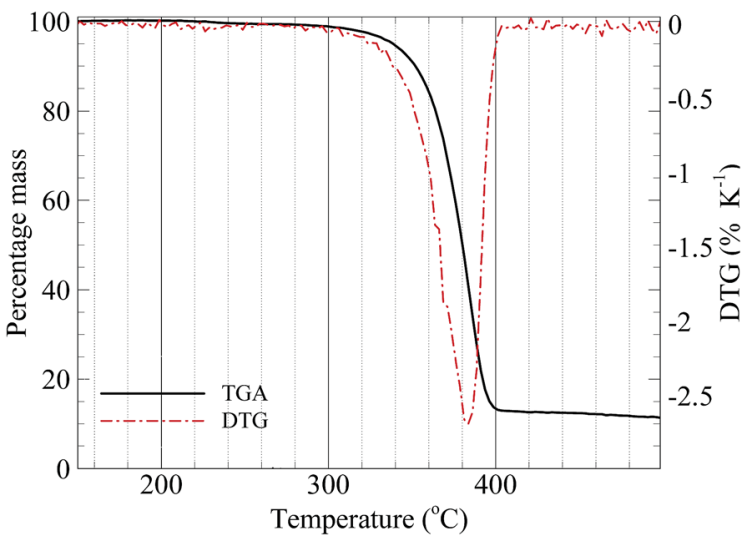

Fig. 3 TGA-DTG of DPTrizDMBHC at $10 \mathrm{~K} \mathrm{~min}^{-1}$.

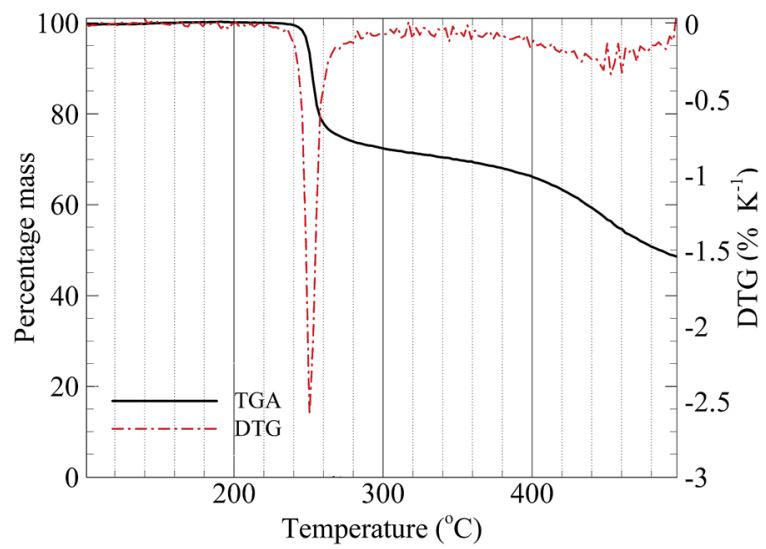

Fig. 4 TGA-DTG of DTetzBHC at $5 \mathrm{~K} \mathrm{~min}^{-1}$.

evolved gases at various temperatures are displayed in Figs. 5-7. The temperatures were typically chosen to display the evolved gases near the extrapolated onset temperatures and around the DTG peaks. Fig. 5 shows the FTIR spectra acquired at $125{ }^{\circ} \mathrm{C}$ and $199^{\circ} \mathrm{C}$ during the thermolysis of 2 . A comparison of the spectrum at $125{ }^{\circ} \mathrm{C}$ with the condensed phase spectrum of the same compound shows that the $\mathrm{C}-\mathrm{H}$ bands near $3000 \mathrm{~cm}^{-1}$, the azide stretch at $2100 \mathrm{~cm}^{-1}$, and the bands in the fingerprint region matched reasonably well, thus confirming evaporation as the dominant process during the initial phase. An inspection of the second spectrum at $199{ }^{\circ} \mathrm{C}$ near the end of the process showed that despite the similarity in the location of the bands, the intensity of the azide band was noticeably higher compared to the spectrum at $125^{\circ} \mathrm{C}$. Also conspicuous by their absence were the bands near $1000 \mathrm{~cm}^{-1}$. However, the lack of smaller molecules that would be typically generated due to decomposition, namely $\mathrm{HCN}$, ethylene, acetylene, or cyclic hydrocarbons, which could be produced by ring opening, ruled out the condensed-phase decomposition of 2 , and instead pointed to a possible dimerization of the compound in either the condensed phase or the colder gas phase. It was also notable that the difference between the onset and end temperatures was $45{ }^{\circ} \mathrm{C}$, which was comparable to the other BHC-based compounds. 


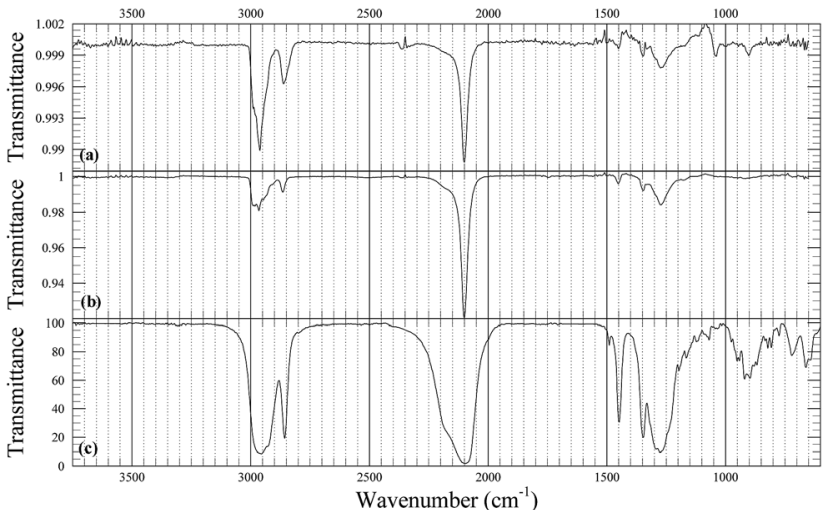

Fig. 5 Comparison of vibrational spectra of DADMBHC: (a) products at $125^{\circ} \mathrm{C}$ and (b) $199^{\circ} \mathrm{C}$ at $10 \mathrm{~K} \mathrm{~min}^{-1}$, and (c) condensed phase.

Fig. 6 shows the FTIR spectra acquired at $354{ }^{\circ} \mathrm{C}$ and $398{ }^{\circ} \mathrm{C}$ during the thermolysis of 3 . Owing to the continuous purging of the FTIR gas cell during the course of the event, the initial $\mathrm{H}_{2} \mathrm{O}$ and $\mathrm{CO}_{2}$ present in the cell were constantly purged out, which was manifested by a transmittance signal greater than the one corresponding to those two species. The spectra were postprocessed to remove the lines from those two species, and thus contain certain spurious peaks from the subtraction process. The spectrum at $354{ }^{\circ} \mathrm{C}$ shows the unmistakable presence of ammonia, with its rotational doublet at 932 and $968 \mathrm{~cm}^{-1}$, as well as the presence of $\mathrm{HN}_{3}$, with its azide stretch at $2140 \mathrm{~cm}^{-1}$. The presence of these two nitrogen containing species, as well as an onset temperature that was $200^{\circ} \mathrm{C}$ higher than that of $\mathbf{2 \text { , }}$ pointed to the pyrolysis of the triazole-based compound. The second spectrum at $398{ }^{\circ} \mathrm{C}$ showed the presence of $\mathrm{NH}_{3}$, and $\mathrm{HN}_{3}$, as well as several other bands. Among them, the stretches near $3050,1480,1040$, and $670 \mathrm{~cm}^{-1}$ were indicative of a compound containing a phenyl group, and a stretch at $3500 \mathrm{~cm}^{-1}$ pointed towards a secondary amine. Additionally, there were stretches around 3280, 3000, 1130, 1080, and $760 \mathrm{~cm}^{-1}$ that were similar to the parent compound.

The decomposition of the compound is expected to proceed through the liberation of molecular nitrogen from the

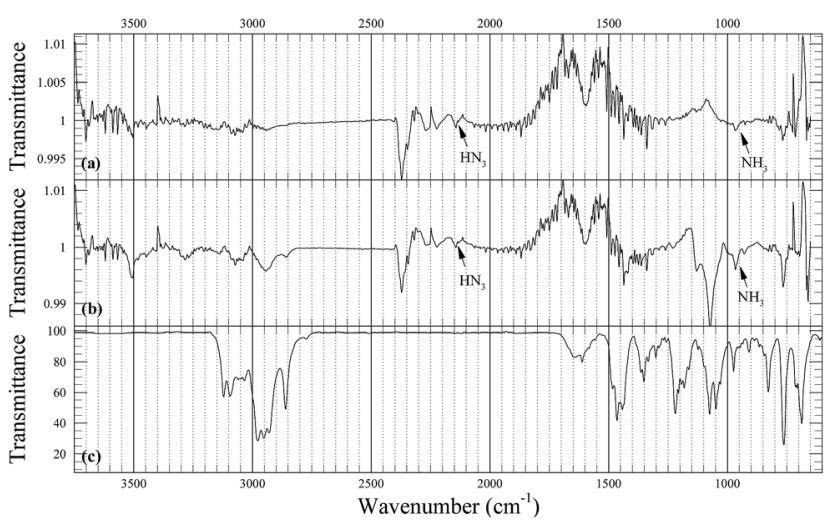

Fig. 6 Comparison of vibrational spectra of DPTrizDMBHC: (a) products at $354{ }^{\circ} \mathrm{C}$ and (b) $398^{\circ} \mathrm{C}$ at $10 \mathrm{~K} \mathrm{~min}^{-1}$, and (c) condensed phase. 1,2,3-triazole substituent, and the subsequent breakdown of the remaining radical through multiple simultaneous pathways. A thorough analysis of the pathways leading to an observed mass loss of $90 \%$ during the process is beyond the scope of this work, and would be pursued with the aid of molecular dynamics simulations in future endeavors.

The spectra acquired at $250{ }^{\circ} \mathrm{C}, 262{ }^{\circ} \mathrm{C}$, and $402{ }^{\circ} \mathrm{C}$ during the thermolysis of $\mathbf{5}$, which is thermally less stable than $\mathbf{3}$, are shown in Fig. 7. The tetrazole based compound was found to lose approximately $26 \%$ of the initial mass rapidly at around $250{ }^{\circ} \mathrm{C}$, which was around $100{ }^{\circ} \mathrm{C}$ higher than the onset temperature of 2 . The spectrum acquired near the onset temperature clearly shows the azide stretch of $\mathrm{HN}_{3}$. The second spectrum, recorded at $12{ }^{\circ} \mathrm{C}$ higher than the onset temperature, shows the presence of $\mathrm{HN}_{3}$ at 2140 and $1150 \mathrm{~cm}^{-1}, \mathrm{NH}_{3}$ at 932 and $968 \mathrm{~cm}^{-1}$, and $\mathrm{NH}_{2} \mathrm{CN}$ at around $2280 \mathrm{~cm}^{-1}$. ${ }^{66}$ These byproducts and the lack of other bands, coupled with the $26 \%$ mass loss in this stage indicates a $\mathrm{C}-\mathrm{C}$ bond scission to liberate one tetrazole moiety, and subsequent decomposition of the tetrazole to form the observed compounds. It is also expected that $\mathrm{N}_{2}$ would be a prominent product during this process, which could not be detected due to the IR-inactivity of the molecule. The thermal decomposition of $2-H$-tetrazole is typically accompanied by the formation of $\mathrm{HN}_{3}, \mathrm{~N}_{2}, \mathrm{NH}_{2} \mathrm{CN}$, and HCN. ${ }^{67}$ Although the presence of $\mathrm{NH}_{3}$ and the lack of $\mathrm{HCN}$ have complicated the exact determination of the initiation pathways during decomposition in the first stage, the matter was not pursued further in this work. The spectrum at $402{ }^{\circ} \mathrm{C}$ at the onset of the second stage shows the presence of $\mathrm{NH}_{3}, \mathrm{NH}_{2} \mathrm{CN}$, $\mathrm{CH}_{4}$ at $3020 \mathrm{~cm}^{-1}$, and $\mathrm{HCN}$ at $712 \mathrm{~cm}^{-1}$. $\mathrm{HN}_{3}$ could not be detected at this stage. Although a mass loss of another $26 \%$ at this stage was indicative of the loss of another tetrazole moiety from the structure, the slow rate of mass loss, the presence of $\mathrm{CH}_{4}$, and the small bands near $3000 \mathrm{~cm}^{-1}$ designating $\mathrm{C}-\mathrm{H}$ stretches, show that the actual decomposition pathways in the

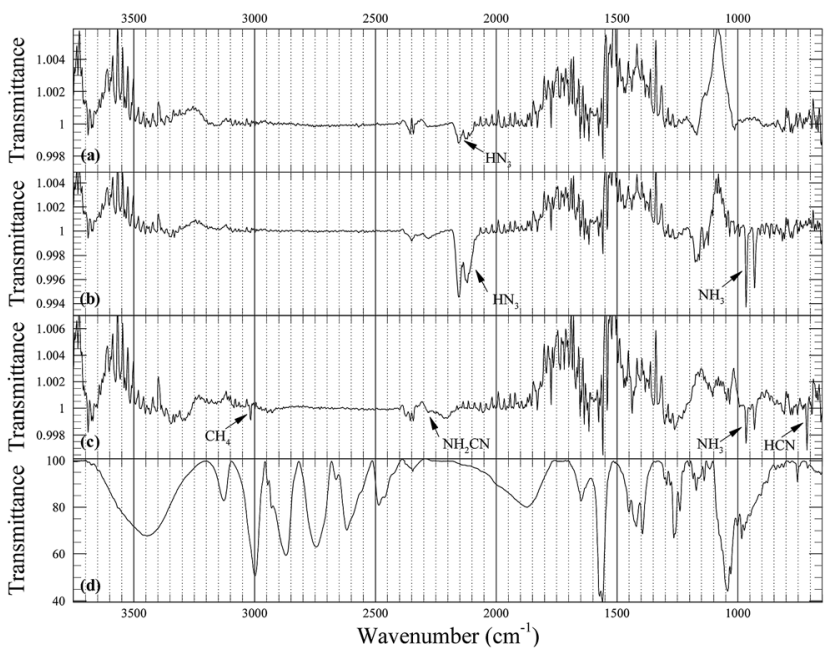

Fig. 7 Comparison of vibrational spectra of DTetzBHC: (a) products at $250{ }^{\circ} \mathrm{C}$ (b) $262{ }^{\circ} \mathrm{C}$ and (c) $402{ }^{\circ} \mathrm{C}$ at $5 \mathrm{~K} \mathrm{~min}^{-1}$, and (d) condensed phase. 
second stage would be more complicated, and would also be undertaken in a future study.

\section{Thermal decomposition analysis}

To complement the experimental work, initiation of decomposition in the three high-nitrogen bishomocubanes was studied using computational techniques. The B3LYP/6-31++G(d,p) level of theory was used in these calculations because a number of radicals are involved. Four decomposition pathways were analyzed for each of the three compounds:

(1) Release of the high-nitrogen group $\left(-\mathrm{CH}_{2}-\mathrm{X}\right.$ or $\left.-\mathrm{X}\right)$ from the cage along with a neighboring hydrogen atom to form $\mathrm{CH}_{3}-$ $\mathrm{X}$ and a bishomocubene.

(2) Release of nitrogen from the high-nitrogen substituent.

(3) Scission of the longest $\mathrm{C}-\mathrm{C}$ bond in the cage.

(4) Scission of the second longest $\mathrm{C}-\mathrm{C}$ bond in the cage.

Decomposition pathways of 2 are shown in Fig. 8 along with the heats of reaction (HoRs) of the respective reactions. It can be observed that the pathway in which the azide $\left(-\mathrm{N}_{3}\right)$ group separates from the cage along with a $\mathrm{H}$ atom on the neighbouring $\mathrm{C}$ atom to form methyl azide $\left(\mathrm{CH}_{3} \mathrm{~N}_{3}\right)$ and bishomocubene $\mathbf{8}$ is very energy intensive. As far as the HoR is concerned, the formation of diradicals $\mathbf{9}$ or $\mathbf{1 0}$ from the cage $\mathrm{C}-\mathrm{C}$ bond breakage is more probable. The release of nitrogen from the azide groups to form the nitrene 7 is equally probable as the HoR for this reaction is comparable to that of the $\mathrm{C}-\mathrm{C}$ bond breaking reactions. Unlike 2 the release of nitrogen in the case of 5 is highly improbable as shown in Fig. 9, because this process is highly endothermic.

Previous research on the decomposition of tetrazole-based compounds also shows that the release of nitrogen from the tetrazole ring requires a lot of energy and is likely to be dominated by alternative pathways. ${ }^{\mathbf{5 8}, 67}$ Also for 5, among the two cage $\mathrm{C}-\mathrm{C}$ bond breaking pathways, the one forming diradical 13 is dominant over that forming diradical 14, whereas in the case of 2 both these pathways were seen to be competing with each other. The pathway forming tetrazolo-bishomocubane $\mathbf{1 1}$ followed by bishomocubene $\mathbf{8}$ is also considerably more endothermic than the cage-opening pathways. Fig. 10 shows the possible thermal decomposition initiation pathways for 3. We observe that it behaves in a fashion similar to 5 . The $\mathrm{C}-\mathrm{C}$ cage

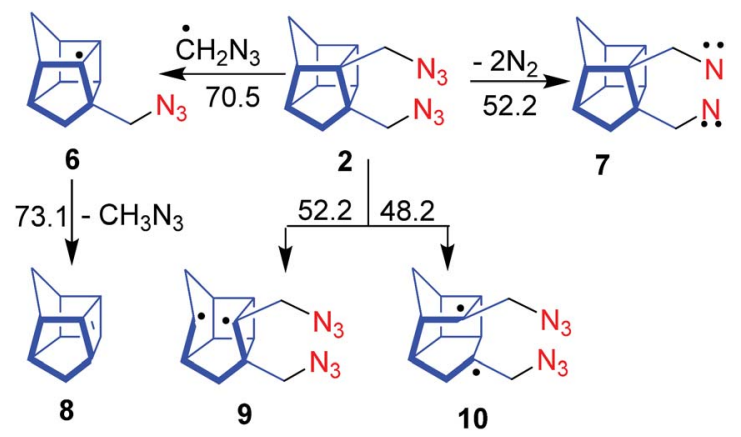

Fig. 8 Thermal decomposition pathways of DADMBHC along with heats of reaction in $\mathrm{kcal} \mathrm{mol}^{-1}$.

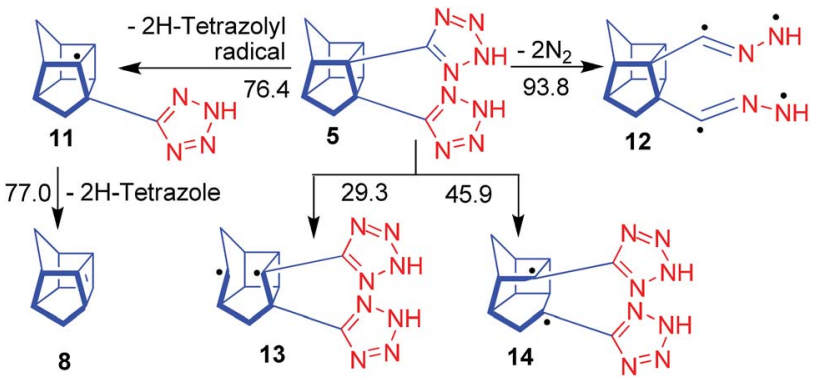

Fig. 9 Thermal decomposition pathways of DTetzBHC along with heats of reaction in $\mathrm{kcal} \mathrm{mol}^{-1}$.

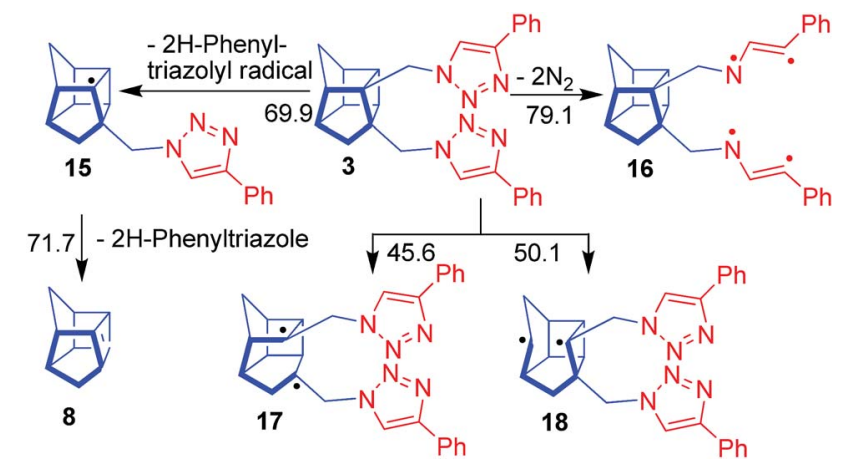

Fig. 10 Thermal decomposition pathways of DPTrizDMBHC along with heats of reaction in $\mathrm{kcal} \mathrm{mol}^{-1}$.

bond breaking pathways are considerably less endothermic and hence can be considered to be dominant over the other two pathways considered, i.e. formation of phenyl-triazolo-methylbishomocubene 15 and nitrogen elimination. Among all the reactions discussed in this work, for those which involve breaking of a single bond, the HoR is equal to the Bond Dissociation Energy (BDE). It should be noted that the conclusions drawn in this work regarding the dominance of various pathways is based on the values of HoR. A more thorough computational study which involves the optimization of transition states and minimum energy path (MEP) calculations will provide more information about the initiation reactions in the decomposition process of high-nitrogen bishomocubanes. Such a study along with a more comprehensive experimental investigation would be a part of our future endeavours. Additionally, attempts will be made to explain the products observed during the decomposition of $\mathbf{5}$ and $\mathbf{3}$ using the molecular dynamics simulations.

\section{Conclusions}

Three new polycyclic high-nitrogen cage compounds-DADMBHC, DTetzBHC, and DPTrizDMBHC-were synthesized and analyzed by using ab initio methods, thermogravimetric analysis, and IR spectroscopy. DADMBHC is a liquid under standard conditions and has potential application as a direct replacement for RP1, owing to its improved density specific impulse (by approximately $80 \mathrm{~s}$ ). DTetzBHC may be utilized as an additive in RP1, thereby 
providing an improvement in density specific impulse of $28 \mathrm{~s}$. These compounds are also potential monomer units for energetic binders in solid propellant formulations, thereby showing an improvement of up to $34 \mathrm{~s}$ over HTPB. DADMBHC, DTetzBHC, and DPTrizDMBHC also possessed relatively high heats of formation of $265.7,271.4$, and $347.8 \mathrm{kcal} \mathrm{mol}^{-1}$ and specific gravities of $1.38,1.54$, and 1.19 , respectively. These compounds also possessed high heats of combustion of approximately $30 \mathrm{MJ} \mathrm{kg}{ }^{-1}$. TGA, coupled with IR spectroscopy, revealed that DADMBHC and DPTrizDMBHC evaporate readily while DTetzBHC is comparatively less stable and decomposes partially. Product species for each of the compounds were detected but these results demand further investigation in detail. Computational studies were able to establish the precedence of scission of some bonds over others to some extent for the decomposition of DADMBHC, DTetzBHC and DPTrizDMBHC. Further computational analysis involving transition state optimizations and minimum energy path calculations to concretely establish the decomposition pathways of these compounds will be part of our future efforts.

\section{Experimental section}

\section{Caution}

Starting materials and compounds reported here are highenergy density materials. Their impact and friction sensitivities are not known. Hence, while handling them one needs to be extremely careful and follow all the standard safety precautions along with the use of equipment such as leather gloves, leather coat, face shields and ear plugs.

\section{General}

Thermogravimetric analysis (TGA) of the compounds was performed on a Netzsch TG209 F1 Libra thermogravimetric analyzer, which was coupled to a Bruker Vertex 80 FTIR spectrometer along with its accompanying optics through a transfer line to identify the evolved gases. Briefly, the compounds (approximately $1 \mathrm{mg}$ ) were heated in an open $\mathrm{Al}_{2} \mathrm{O}_{3}$ crucible under a constant nitrogen (99.995\% purity) flow at a purge flow rate of $120 \mathrm{~mL} \mathrm{~min}{ }^{-1}$. The protective purge flow rate was set to $10 \mathrm{~mL} \mathrm{~min}^{-1}$, which was adequate for effectively transferring the gases from the TGA module into the FTIR spectrometer through a heated PTFE transfer tube, which was maintained at $210^{\circ} \mathrm{C}$. The gases were transported into a heated gas cell, which was equipped with two $\mathrm{KBr}$ windows and two ZnSe windows, at $190{ }^{\circ} \mathrm{C}$. The FTIR spectra of the gases were recorded from $3750-650 \mathrm{~cm}^{-1}$, with a spectroscopic resolution of $4 \mathrm{~cm}^{-1}$. The compounds were heated from $30-250{ }^{\circ} \mathrm{C}$ at three heating rates of $2.5,5$, and $10 \mathrm{~K} \mathrm{~min}^{-1}$.

\section{2,5-Bis(azidomethyl)pentacyclo[5.3.0.0 $\left.{ }^{2,5} \cdot 0^{3,9} \cdot 0^{4,8}\right]$ decane (2)}

To the cage diol 1 (300 mg, $1.56 \mathrm{mmol})$ in dry $\mathrm{CH}_{2} \mathrm{Cl}_{2}(20 \mathrm{~mL})$, cooled to $0{ }^{\circ} \mathrm{C}$, was added pyridine $(0.8 \mathrm{~mL}, 766 \mathrm{mg}, 9.6 \mathrm{mmol}$, 6.1 equiv.) followed by mesyl chloride $(0.73 \mathrm{~mL}, 1.070 \mathrm{~g}$, $9.4 \mathrm{mmol}, 6$ equiv.) and DMAP (38 $\mathrm{mg}, 20 \mathrm{~mol} \%)$. The reaction mixture was stirred for $1 \mathrm{~h}$ at $0{ }^{\circ} \mathrm{C}$ and kept in a refrigerator overnight. It was diluted with water $(15 \mathrm{~mL})$, extracted with $\mathrm{CH}_{2} \mathrm{Cl}_{2}(3 \times 10 \mathrm{~mL})$ and the combined organic layer was thoroughly washed with water $(5 \times 10 \mathrm{~mL})$ to remove the excess mesyl chloride followed by saturated $\mathrm{NaHCO}_{3}(3 \times$ $10 \mathrm{~mL})$ and $5 \%$ dil $\mathrm{HCl}(3 \times 10 \mathrm{~mL})$. The organic layer was dried over anhydrous $\mathrm{Na}_{2} \mathrm{SO}_{4}$ and concentrated in vacuo. The crude mesylate $(500 \mathrm{mg}, 92 \%)$ was suspended in DMF (8 mL) to which $\mathrm{NaN}_{3}(780 \mathrm{mg}, 12 \mathrm{mmol})$ was added followed by TBAB (68 $\mathrm{mg}, 0.3 \mathrm{mmol})$. Then the reaction mixture was heated at $90{ }^{\circ} \mathrm{C}$ for $12 \mathrm{~h}$ and extracted with ethyl acetate $(3 \times$ $10 \mathrm{~mL}$ ). The combined organic layer was concentrated in vacuo and the residue was purified by silica gel column chromatography (pet ether) to afford diazide 2 as colorless oil; $261 \mathrm{mg}, 69 \%$ yield. IR (film, cm ${ }^{-1}$ ) 2958 (s), 2856 (m), 2097 (vs), 1448 (m), 1347 (m), and 1275 (s); ${ }^{1} \mathrm{H}$ NMR $\left(\mathrm{CDCl}_{3}, 400\right.$ $\mathrm{MHz}) \delta 1.35$ (d, $J=10.1 \mathrm{~Hz}, 1 \mathrm{H}), 1.37$ (d, $J=11.3 \mathrm{~Hz}, 1 \mathrm{H}), 1.60$ (d, $J=11.3 \mathrm{~Hz}, 1 \mathrm{H}), 1.73(\mathrm{~d}, J=10.1 \mathrm{~Hz}, 1 \mathrm{H}), 2.44-2.50(\mathrm{~m}$, $4 \mathrm{H}$ ), 2.72-2.76 (d of quintet, $J=5.8,1.4 \mathrm{~Hz}, 1 \mathrm{H}), 2.80-2.84(\mathrm{~m}$, $1 \mathrm{H}), 3.37,3.46(\mathrm{ABq}, J=12.4 \mathrm{~Hz}, 2 \mathrm{H}), 3.68$, and $3.72(\mathrm{ABq}, J=$ $12.4 \mathrm{~Hz}, 2 \mathrm{H}) ;{ }^{13} \mathrm{C}\left(\mathrm{CDCl}_{3}, 100 \mathrm{MHz}\right) \delta 37.7(\mathrm{t}), 39.6(\mathrm{~d}), 40.5(\mathrm{t})$, 41.2 (d), 42.3 (d), 43.8 (d), 47.1 (d), $51.9(\mathrm{~d}), 52.2(\mathrm{t}), 53.4(\mathrm{t})$, $55.1(\mathrm{~s})$, and $55.7(\mathrm{~s})$; MS (QTOF $\mathrm{ES}^{+}$) $\mathrm{m} / z$ (relative intensity) $281\left(\mathrm{MK}^{+}, 100\right)$; HRMS calcd for $\mathrm{C}_{12} \mathrm{H}_{14} \mathrm{~N}_{6} \mathrm{~K}\left(\mathrm{M}^{+}\right)$281.4018,

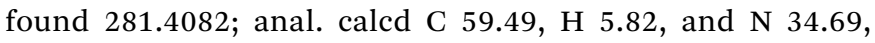
found C 59.53, H 5.52, and N 34.47.

\section{1,2-Bis((4-phenyl-1H-1,2,3-triazol-1-1)methyl)pentacyclo- $\left[5.3 .0 .0^{2,5} \cdot 0^{3,9} .0^{4,8}\right]$-decane $(3, \mathrm{R}=\mathrm{Ph})$}

Cage diazide 2 (100 $\mathrm{mg}, 0.413 \mathrm{mmol}$ ) was suspended in a $t$-BuOH-water mixture $(1: 1,2 \mathrm{~mL})$. To this suspension, phenyl acetylene $(0.1 \mathrm{~mL}, 84 \mathrm{mg}, 0.82 \mathrm{mmol}, 2$ equiv.), sodium ascorbate $(17 \mathrm{mg}, 0.08 \mathrm{mmol}, 0.2$ equiv., in two drops of water $)$, and $\mathrm{CuSO}_{4} \cdot 5 \mathrm{H}_{2} \mathrm{O}(11 \mathrm{mg}, 0.04 \mathrm{mmol})$ were added and the reaction mixture was stirred at room temperature for $8 \mathrm{~h}$. The reaction mixture was then extracted with $\mathrm{CH}_{2} \mathrm{Cl}_{2}(3 \times 5$ $\mathrm{mL}$ ), the combined organic layer was washed with brine $(10 \mathrm{~mL})$, dried over anhydrous $\mathrm{Na}_{2} \mathrm{SO}_{4}$ and concentrated in vacuo. The residue was purified by silica gel column chromatography (EtOAc/pet ether $1: 4$ ) to afford 3 as a white solid; $105 \mathrm{mg}, 57 \%$ yield, mp 234-236 ${ }^{\circ} \mathrm{C}$. IR (KBr, $\left.\mathrm{cm}^{-1}\right) 3121(\mathrm{~m})$, 3094 (m), 2977 (s), 2951 (s), 2930 (s), 2860 (m), 1639 (w), 1611 (w), 1465 (s), 1441 (s), 1351 (m), 1219 (s), 1074 (s), 1048 (s), 761 $(\mathrm{s})$, and $686(\mathrm{~s}) ;{ }^{1} \mathrm{H}$ NMR $\left(400 \mathrm{MHz}, \mathrm{CDCl}_{3}\right) \delta 0.95(\mathrm{~d}, J=11.3$ $\mathrm{Hz}, 1 \mathrm{H}), 1.25$ (d, $J=10.4 \mathrm{~Hz}, 1 \mathrm{H}), 1.52$ (d, $J=11.3 \mathrm{~Hz}, 1 \mathrm{H})$, $1.78(\mathrm{~d}, J=10.4 \mathrm{~Hz}, 1 \mathrm{H}), 2.42-2.46(\mathrm{~m}, 2 \mathrm{H}), 2.66-2.69(\mathrm{~m}, 3 \mathrm{H})$, 2.81-2.84 (m, 1H), 4.37 (d, $J=14.6 \mathrm{~Hz}, 1 \mathrm{H}), 4.66(\mathrm{~d}, J=14.6$ $\mathrm{Hz}, 1 \mathrm{H}), 4.99,5.06(\mathrm{ABq}, J=14.2 \mathrm{~Hz}, 2 \mathrm{H}), 7.26-7.45(\mathrm{~m}, 6 \mathrm{H})$, $7.73(\mathrm{~s}, 1 \mathrm{H})$, and $7.83-7.85(\mathrm{~m}, 5 \mathrm{H}) ;{ }^{13} \mathrm{C} \mathrm{NMR}(100 \mathrm{MHz}$, $\left.\mathrm{CDCl}_{3}\right) \delta 37.3(\mathrm{t}), 39.1(\mathrm{~d}), 40.3(\mathrm{t}), 40.9(\mathrm{~d}), 42.4(\mathrm{~d}), 43.4(\mathrm{~d})$, $46.7(\mathrm{~d}), 50.2(\mathrm{t}), 51.2(\mathrm{t}), 51.4(\mathrm{t}), 54.8(\mathrm{~s}), 55.5(\mathrm{~s}), 120.7(\mathrm{~d})$, 120.7 (d), 125.6 (×2, d), 128.1 (d), 128.2 (d), 128.8 (×2, d), 130.5 (s), 130.5 (s), 147.3 (s), and 147.5 (s); MS (QTOF ES ${ }^{+}$) m/z (relative intensity) $448\left([\mathrm{M}+2]^{+}, 5\right), 447\left(\left[\mathrm{MH}^{+}, 100\right), 224(1)\right.$, 214 (5), 158 (8), and 140.9 (1); HRMS calcd for $\mathrm{C}_{28} \mathrm{H}_{27} \mathrm{~N}_{6}\left(\mathrm{M}^{+}\right)$ 447.2297, found 447.2279; anal. calcd C 75.31, H 5.87, and $\mathrm{N}$ 18.82, found C 74.49, H 5.82, and N 18.90 . 
Pentacyclo[5.3.0.0 $\left.{ }^{2,5} \cdot 0^{3,9} \cdot 0^{4,8}\right]$ decane 2,5-dicarbonitrile (4)

The procedure was followed as reported by Mori et al., ${ }^{68}$ a mixture of diol $1(200 \mathrm{mg}, 1.04 \mathrm{mmol})$, aq. $\mathrm{NH}_{3}(3.6 \mathrm{~mL}$, $93.75 \mathrm{mmol})$ and iodine $(1.58 \mathrm{~g}, 6.25 \mathrm{mmol})$ was heated to $75{ }^{\circ} \mathrm{C}$ for $10 \mathrm{~h}$. It was then cooled to $0{ }^{\circ} \mathrm{C}$ and water $(15 \mathrm{~mL})$ was added followed by saturated sodium sulfite $(5 \mathrm{~mL})$. The aqueous layer was extracted with ether $(5 \times 10 \mathrm{~mL})$. The combined organic layer was washed with brine $(2 \times 10 \mathrm{~mL})$, dried (anhydrous $\mathrm{Na}_{2} \mathrm{SO}_{4}$ ) and concentrated in vacuo. The crude dinitrile 4, isolated as a light yellow solid was sufficiently pure, $163 \mathrm{mg}$, 86\% yield, mp 151-153 ${ }^{\circ} \mathrm{C}$; IR ( $\left.\mathrm{KBr}, \mathrm{cm}^{-1}\right) 2990$ (vs), 2936 (s), $2865(\mathrm{~m}), 2233$ (vs), $1449(\mathrm{~m}), 1276(\mathrm{~m}), 951(\mathrm{~m})$, and $731(\mathrm{~m}) ;{ }^{1} \mathrm{H}$ NMR $\left(\mathrm{CDCl}_{3}, 400 \mathrm{MHz}\right) \delta 1.61(\mathrm{~d}, J=12.0 \mathrm{~Hz}, 1 \mathrm{H}), 1.81(\mathrm{~d}, J=$ $12.0 \mathrm{~Hz}, 1 \mathrm{H}), 1.86$ (d, $J=11.7 \mathrm{~Hz}, 1 \mathrm{H}), 2.22$ (d, $J=11.7 \mathrm{~Hz}, 1 \mathrm{H})$, 2.72-2.76 (m, $1 \mathrm{H}), \delta 2.88$ (ddd collapsed to quint, $J=5.8 \mathrm{~Hz}$, $1 \mathrm{H}), 3.00-3.05(\mathrm{~m}, 3 \mathrm{H}), 3.20$, and $3.21(\mathrm{ABq}, J=4.5 \mathrm{~Hz}, 1 \mathrm{H}) ;{ }^{13} \mathrm{C}$ NMR $\left(\mathrm{CDCl}_{3}, 100 \mathrm{MHz}\right) \delta 38.1(\mathrm{t}), 41.1(\mathrm{~d}), 42.2(\mathrm{t}), 42.7$ (d), 43.1 (d), 45.8 (s), 46.3 (d), 46.7 (s), 48.1 (d), 54.0 (d), 117.9 (s), and 118.2 (s); MS (QTOF ES ${ }^{+}$) $\mathrm{m} / z$ (relative intensity) $205\left(\mathrm{MNa}^{+}, 11\right)$, $183\left(\mathrm{MH}^{+}, 100\right)$, and 92 (2); HRMS calcd for $\mathrm{C}_{12} \mathrm{H}_{10} \mathrm{~N}_{2} \mathrm{Na}\left(\mathrm{M}^{+}\right)$ 205.0742, found 205.0744 .

\section{2,5-Bis(2H-tetrazol-5-yl) pentacyclo[5.3.0.0 $\left.{ }^{2,5} \cdot 0^{3,9} \cdot 0^{4,8}\right]$-decane (5)}

A mixture of cage dinitrile $4(0.13 \mathrm{~g}, 0.71 \mathrm{mmol})$, sodium azide $(0.18 \mathrm{~g}, 2.77 \mathrm{mmol})$ and $\mathrm{ZnBr}_{2}(0.16 \mathrm{~g}, 0.71 \mathrm{mmol})$ in water $(12 \mathrm{~mL})$ and isopropanol $(12 \mathrm{~mL})$ was heated at $80^{\circ} \mathrm{C}$ for $24 \mathrm{~h}$. It was then cooled and $3 \mathrm{~N} \mathrm{HCl}(5 \mathrm{~mL})$ and ethyl acetate $(10 \mathrm{~mL})$ were added and the resulting mixture was stirred until no solid remained. Then the aqueous layer was extracted with ethyl acetate $(5 \times 10 \mathrm{~mL})$, washed with brine $(2 \times 10 \mathrm{~mL})$, dried over anhydrous $\mathrm{Na}_{2} \mathrm{SO}_{4}$ and concentrated in vacuo. The crude residue was purified by recrystallization from methanol and ethyl acetate (1:4 ratio) to afford pure bis-tetrazole 5 as a colorless solid, $116 \mathrm{mg}, 61 \%$ yield, $\mathrm{mp} 250-251{ }^{\circ} \mathrm{C}$ (decomp); IR (KBr, cm $\left.{ }^{-1}\right) 3461$ (br, m), 3126 (m), 3001 (s), 2871 (m), 2762 (m), 1647 (m), 1595 (s), 1566 (s), 1451 (m), 1417 (s), 1391 (s), 1294 (m), 1256 (s), 1241 (s), and 1053 (s); ${ }^{1} \mathrm{H}$ NMR (CD ${ }_{3} \mathrm{OD}$, $400 \mathrm{MHz}) \delta 1.46(\mathrm{~d}, J=11.6 \mathrm{~Hz}, 1 \mathrm{H}), 1.86(\mathrm{~d}, J=11.6 \mathrm{~Hz}, 1 \mathrm{H})$, $1.97(\mathrm{~d}, J=11.3 \mathrm{~Hz}, 1 \mathrm{H}), 2.65$ (d, $J=11.3 \mathrm{~Hz}, 1 \mathrm{H}), 2.92-2.94$ (unresolved $\mathrm{m}, 1 \mathrm{H}), 3.07-3.18(\mathrm{~m}, 4 \mathrm{H}), 3.31$ (ddd collapsed to quint, $J=1.6 \mathrm{~Hz}, 1 \mathrm{H}), 3.50$, and $3.52(\mathrm{ABq}, J=4.6 \mathrm{~Hz}, 2 \mathrm{H}) ;{ }^{13} \mathrm{C}$ NMR (CD $\mathrm{OD}, 100 \mathrm{MHz}) \delta 38.6(\mathrm{t}), 42.0(\mathrm{t}), 42.6(\mathrm{~d}), 42.9(\mathrm{~d})$, 45.1 (d), 45.7 (d), 46.8 (d), 54.7 (s), 55.4 (s), 56.6 (d), 157.2 (s), and 158.3 (s); MS (TOF ES $\left.{ }^{+}\right) \mathrm{m} / z$ (relative intensity) $269\left(\mathrm{MH}^{+}\right.$, 100); HRMS calcd for $\mathrm{C}_{12} \mathrm{H}_{13} \mathrm{~N}_{8}\left(\mathrm{MH}^{+}\right)$269.1263, found 269.1251; anal. calcd C 53.72, H 4.51, and N 41.77, found C 53.12, $\mathrm{H} 4.44$, and $\mathrm{N} 42.06$.

\section{Acknowledgements}

The authors acknowledge the financial support provided by the Indian Space Research Organization (ISRO) and Armament Research and Development Board (ARDB) as well as the Industrial Research and Consultancy Centre (IRCC) at the Indian Institute of Technology Bombay.

\section{Notes and references}

1 J. P. Agrawal, Prog. Energy Combust. Sci., 1998, 24, 1-30.

2 P. E. Eaton and T. W. Cole, J. Am. Chem. Soc., 1964, 86, 31573158.

3 P. E. Eaton and M. X. Zhang, Proceedings of 9th ONR Propulsion Meeting, State University of New York, Buffalo, NY, 1996.

4 B. D. Kybett, S. Carroll, P. Natalis, D. W. Bonnell, J. L. Margrave and J. L. Franklin, J. Am. Chem. Soc., 1966, 88, 626.

5 P. E. Eaton, F. Alberici, L. Cassar, F. Monti, C. Neri and N. Nodari, US Pat., US4943302A, 1990.

6 P. E. Eaton, Proceedings of the 7th ONR Propulsion Meeting, State University of New York, Buffalo, NY, 1994.

7 P. E. Eaton, Y. Xiong and R. Gilardi, J. Am. Chem. Soc., 1993, 115, 10195-10202.

8 A. P. Marchand, Advances in Theoretically Interesting Molecules, JAI Press, Greenwich, CT, 1989.

9 A. P. Marchand, Z. Liu, D. Rajagopal, V. D. Sorokin, F. Zaragoza and A. Zope, Proceedings of the 7th ONR Propulsion Meeting, State University of New York, Buffalo, NY, 1994.

10 R. Butcher, A. Bashir-Hashemi and R. Gilardi, J. Chem. Crystallogr., 1997, 27, 99-107.

11 A. K. Sikder and N. Sikder, J. Hazard. Mater., 2004, 112, 1-15. 12 L. E. Fried, M. R. Manaa, P. F. Pagoria and R. L. Simpson, Annu. Rev. Mater. Res., 2001, 31, 291-321.

13 P. F. Pagoria, G. S. Lee, A. R. Mitchell and R. D. Schmidt, Thermochim. Acta, 2002, 384, 187-204.

14 P. E. Eaton, R. L. Gilardi and M. X. Zhang, Adv. Mater., 2000, 12, 1143-1148.

15 A. P. Marchand, Chem. Rev., 1989, 89, 1011-1033.

16 A. P. Marchand, Aldrichimica Acta, 1995, 28, 95-104.

17 P. E. Eaton, Angew. Chem., Int. Ed., 1992, 31, 1421-1436.

18 K. A. Lukin, J. Li, P. E. Eaton, N. Kanomata, J. Hain, E. Punzalan and R. Gilardi, J. Am. Chem. Soc., 1997, 119, 9591-9602.

19 S. Rajkumar, R. S. Choudhari, A. Chowdhury and I. N. N. Namboothiri, Thermochim. Acta, 2013, 563, 38-45.

20 S. Lal, S. Rajkumar, A. Tare, S. Reshmi, A. Chowdhury and I. N. N. Namboothiri, Chem. Asian J., 2014, 9, 3533-3541.

21 G. Mehta and H. S. P. Rao, Tetrahedron, 1998, 54, 1332513370.

22 T. X. Li, D. L. Zhu and C. K. Law, J. Propul. Power, 1998, 14, 45-50.

23 G. D. Roy, J. Propul. Power, 2000, 16, 546-551.

24 C. Segal, S. Pethe and K. R. Williams, Combust. Sci. Technol., 2001, 163, 229-244.

25 Z. Li and S. L. Anderson, J. Phys. Chem. A, 2003, 107, 11621174.

26 M. A. Hiskey, N. Goldman and J. R. Stine, J. Energ. Mater., 1998, 16, 119-127.

27 T. M. Klapötke and T. G. Witkowski, Propellants Explos. Pyrotech., 2015, 40, 366-373. 
28 V. G. Kiselev and N. P. Gritsan, J. Phys. Chem. A, 2009, 113, 3677-3684.

29 K. W. Paul, M. M. Hurley and K. K. Irikura, J. Phys. Chem. A, 2009, 113, 2483-2490.

30 J.-G. Zhang, L.-N. Feng, S.-W. Zhang, T.-L. Zhang and H.-H. Zheng, J. Mol. Mod., 2008, 14, 403-408.

31 N. Piekiel and M. R. Zachariah, J. Phys. Chem. A, 2012, 116, 1519-1526.

32 M. Malow, K. D. Wehrstedt and S. Neuenfeld, Tetrahedron Lett., 2007, 48, 1233-1235.

33 N. Sasidharan, B. Hariharanath and A. G. Rajendran, Thermochim. Acta, 2011, 520, 139-144.

34 K. S. Rao, F. Yehya, A. K. Chaudhary, A. S. Kumar and A. K. Sahoo, J. Anal. Appl. Pyrolysis, 2014, 109, 132-139.

35 H. Zhou, Z.-l. Ma, J.-l. Wang and D. Wang, Def. Technol., 2014, 10, 384-392.

36 M. J. Frisch, G. W. Trucks, H. B. Schlegel, G. E. Scuseria, M. A. Robb, J. R. Cheeseman, G. Scalmani, V. Barone, B. Mennucci, G. A. Petersson, H. Nakatsuji, M. Caricato, X. Li, H. P. Hratchian, A. F. Izmaylov, J. Bloino, G. Zheng, J. L. Sonnenberg, M. Hada, M. Ehara, K. Toyota, R. Fukuda, J. Hasegawa, M. Ishida, T. Nakajima, Y. Honda, O. Kitao, H. Nakai, T. Vreven, J. A. Montgomery Jr., J. E. Peralta, F. Ogliaro, M. Bearpark, J. J. Heyd, E. Brothers, K. N. Kudin, V. N. Staroverov, R. Kobayashi, J. Normand, K. Raghavachari, A. Rendell, J. C. Burant, S. S. Iyengar, J. Tomasi, M. Cossi, N. Rega, N. J. Millam, M. Klene, J. E. Knox, J. B. Cross, V. Bakken, C. Adamo, J. Jaramillo, R. Gomperts, R. E. Stratmann, O. Yazyev, A. J. Austin, R. Cammi, C. Pomelli, J. W. Ochterski, R. L. Martin, K. Morokuma, V. G. Zakrzewski, G. A. Voth, P. Salvador, J. J. Dannenberg, S. Dapprich, A. D. Daniels, Ö. Farkas, J. B. Foresman, J. V. Ortiz, J. Cioslowski and D. J. Fox, Gaussian 09, Revision D.01, Gaussian Inc., Wallingford CT, 2009.

37 P. J. Stephens, F. J. Devlin, C. F. Chabalowski and M. J. Frisch, J. Phys. Chem., 1994, 98, 11623-11627.

38 W. J. Hehre, R. Ditchfield and J. A. Pople, J. Chem. Phys., 1972, 56, 2257-2261.

39 R. Krishnan, J. S. Binkley, R. Seeger and J. A. Pople, J. Chem. Phys., 1980, 72, 650-654.

40 T. Clark, J. Chandrasekhar, G. W. Spitznagel and P. v. R. Schleyer, J. Comput. Chem., 1983, 4, 294-301.

41 Z. X. Chen, J. M. Xiao, H. M. Xiao and Y. N. Chiu, J. Phys. Chem. A, 1999, 103, 8062-8066.

42 B. M. Rice, S. V. Pai and J. Hare, Combust. Flame, 1999, 118, 445-458.

43 L. A. Curtiss, K. Raghavachari, P. C. Redfern and J. A. Pople, J. Chem. Phys., 1997, 106, 1063-1079.

44 A. Osmont, L. Catoire, I. Gökalp and V. Yang, Combust. Flame, 2007, 151, 262-273.

45 A. Nicolaides, A. Rauk, M. N. Glukhovtsev and L. Radom, J. Phys. Chem., 1996, 100, 17460-17464.
46 K. E. Gutowski, J. D. Holbrey, R. D. Rogers and D. A. Dixon, J. Phys. Chem. B, 2005, 109, 23196-23208.

$47 \mathrm{~S}$. Gordon and B. J. McBride, Computer Program for Calculation of Complex Chemical Equilibrium Compositions and Applications, in NASA Reference Publication 1311, 1996.

48 NIST Chemistry Webbook, http://webbook.nist.gov/ chemistry/, accessed September 2014.

49 J. Akhavan, The Chemistry of Explosives, Royal Sociey of Chemistry, Cambridge, 2nd edn, 2004.

50 M. J. Kamlet and S. J. Jacobs, J. Chem. Phys., 1968, 48, 23-35. 51 A. P. Marchand, H. K. Hariprakasha and I. N. N. Namboothiri, Synth. Commun., 2001, 31, 1863-1869. 52 I. N. N. Namboothiri, O. P. Oommen, S. Rajkumar and N. Ayyagari, Indian Patent, 2014, 262807.

53 F. H. Allen, O. Kennard, D. G. Watson, L. Brammer, A. G. Orpen and R. Taylor, J. Chem. Soc., Perkin Trans. 2, 1987, S1-S19.

54 Y. Zhao and D. Truhlar, Theor. Chem. Acc., 2008, 120, 215241.

55 Basis Sets, http:/www.gaussian.com/g_tech/g_ur/ m_basis_sets.htm, accessed September 2104.

56 R. P. Singh, H. Gao, D. T. Meshri and J. M. Shreeve, in Structure and Bonding, ed. P. Day, X. Duan, T. J. Meyer, G. Parkin, H. W. Roesky and J.-P. Sauvage, Springer-Verlag, Berlin Heidelberg, 2007, vol. 125, pp. 35-83.

57 W. L. Dilling, J. Org. Chem., 1993, 58, 5338-5344.

58 N. R. Kumbhakarna and S. T. Thynell, Thermochim. Acta, 2014, 582, 25-34.

59 N. R. Kumbhakarna, K. J. Shah, A. Chowdhury and S. T. Thynell, Thermochim. Acta, 2014, 590, 51-65.

60 R. J. Kee, F. M. Rupley and J. A. Miller, Chemkin-ll: a Fortran Chemical Kinetics Package for the Analysis of Gas-Phase Chemical Kinetics, Report SAND89-8009, Sandia National Laboratories, 1989.

61 T. J. Bruno and B. L. Smith, Ind. Eng. Chem. Res., 2006, 45, 4381-4388.

62 M. L. Huber, E. W. Lemmon, L. S. Ott and T. J. Bruno, Energy Fuels, 2009, 23, 3083-3088.

63 G. P. Sutton and O. Biblarz, Rocket Propulsion Elements, John Wiley \& Sons Inc., 2001.

64 J. R. Griffiths, J. Tsanaktsidis, G. P. Savage and R. Priefer, Thermochim. Acta, 2010, 499, 15-20.

65 D. I. Weinstein, J. Alster and A. P. Marchand, Thermochim. Acta, 1986, 99, 133-137.

66 G. D. Wagner and E. L. Wagner, J. Phys. Chem., 1960, 64, 1480-1485.

67 A. I. Lesnikovich, S. V. Levchik, A. I. Balabanovich, O. A. Ivashkevich and P. N. Gaponik, Thermochim. Acta, 1992, 200, 427-441.

68 N. Mori and H. Togo, Synlett, 2005, 9, 1456-1458. 